\title{
The Growth Choices of French Listed SMEs
}

\author{
Nazik Fadil \\ EM Normandie \\ Normandy Business School \\ 30, rue de Richelieu, 76087 Le Havre Cedex, France
}

Tel: 33-02-3292-5673 E-mail: n.fadil@em-normandie.fr

Received: September 9, 2011

Accepted: April 16, $2012 \quad$ Published: June 1, 2012

doi:10.5539/ibr.v5n6p83

URL: http://dx.doi.org/10.5539/ibr.v5n6p83

\begin{abstract}
Many SMEs suffer from financing problems that hinder their growth. To overcome these difficulties, some list on the stock market and make a public offering. Does this favor the SMEs' growth? And what types of growth do SMEs prefer in this context? The empirical study shows an overall positive development of turnover, especially internationally. SMEs seem to focus on external growth at the expense of internal growth and short-term investment in $R \& D$.
\end{abstract}

Keywords: SME, Stock exchange listing, Internal/external growth, Innovation

\section{Introduction}

The presence of SMEs in the stock market is quite rare. Yet listing generates a spiral of growth. From 686 listed companies on Euronext (B \& C) and Alternext, 127 are SMEs. These companies have a growth rate of sales and total assets higher than their unlisted counterparts. They have 50\% more chance to be ranked in the largest size class. The most successful of them outperform unlisted firms in terms of profitability and growth rate (Bank of France, 2010). This leads to strong interest from the political powers. This is especially true as SMEs constitute $99 \%$ of the economic fabric, create more than $60 \%$ of jobs and participate in more than $55 \%$ of GDP (Ministry of Economy, Finance and Employment, 2008). This means that issues of SME funding and growth are crucial. In terms of research, there is little work, especially on French cases. St-Pierre and Mathieu (2003) notice a lack of knowledge of the financing needs of SMEs according to their stage of development, their degree of risk and their evolution prospects. Most studies have looked at alternative sources of financing such as venture capital. Others are interested by the upstream financing of the entrepreneurial adventure like the seed capital proposed by incubators, business angels, family contributions and state aid (Pare et al., 2009). Finally, according to the pecking order theory or the model of the life cycle, the IPO remains the last resort of SMEs, after self-financing and bank debt.

The impact of the IPO on the performance has been the subject of multiple investigations into the American (Jain \& Kini, 1994; Mikkelson et al., 1997) Asian (Cai \& Wei, 1997; Wang, 2005) and European market (Pagano et al., 1998; Sentis, 2001; Coakley et al., 2004; Serve, 2007). Most of these studies find a decline in economic and financial performance (and Mansali Labegorre, 2010). To our knowledge, no study makes clear the impact in terms of strategic behaviour and even less so in the particular case of French SMEs. However, the link between the stock exchange and the performance is not direct, but operates through strategic variables. Indeed, the value theory teaches us that strategic choices, especially in term of growth, are responsible for the variation in performance (Hoareau \& Teller, 2001). Thus, the objective of this paper is to shed light on the impact of IPOs on SMEs growth (measured in terms of turnover in France and abroad) and on the related strategic choices that are privileged in this context of listing (internal growth, external growth, investment in innovation technology).

The interest is twofold: from a practical perspective, this article focuses attention on one part of the constellation of SMEs that chose to be listed on the stock exchange market and explores the implications in term of development choices. This is to ensure that the resources generated by the stock market promote the growth of SMEs. From a theoretical viewpoint, this research contributes to the debate on the effectiveness of IPOs, especially for the little explored case of SMEs and introduces strategic growth variables that could potentially explain this evolution.

The article is divided into four parts. The first provides a literature review that justifies the research question, the second describes the methodology used and the last two parts present and analyze the results. 


\section{Growth of Listed SMEs: A Literature Review}

The studies on SME growth are unanimous about the importance of financial resources to invest andgrow (Krasniqi, 2007; Oliveira \& Fortunato, 2006; Becchetti \& Trovato, 2002; Pissarides, 1999) (Note1). Hambrick and Crozier (1985) and Bruton and Prasad (1997) conclude that the first cause which limits the growth of companies is the lack of liquidity (cash deprivation). Indeed, without financial resources, a company cannot invest and improve its production capacity, its sales and market share at the national level, let alone internationally. It cannot recruit or train staff and thus improve managerial capacity, it cannot diversify risk ... In short, without financial resources, the growth trajectory is altered.

Welbourne et al. (1998) introduce the concept of Entrepreneurial Growth Ceiling (EGC). They consider the IPO as a means to generate financial resources and to break, therefore, this growth ceiling, through investment in human resources and R\&D. This type of investment, according to the authors, reassures shareholders and financial market authorities, creates shareholder value in the short term and ultimately ensures long-term performance. Blowers et al. (1995) identify the benefits of the IPO and cite specifically the improvement of financial resources to support growth "capital to sustain growth", the opportunities for future funding and the means to grow externally "mergers and acquisitions"... In addition to these financial benefits, the stock exchange increases the fame of SMEs and improves their social capital. They earn prestige and visibility and become financially credible vis-à-vis their partners. The stock exchange therefore supports entrepreneurial activity by developing networks of contacts and conditions of access to external financing, providing growth opportunities for SMEs both in the domestic and foreign market (Ravasi \& Marchisio, 2003) (Note 2).

That said, financial resources are not sufficient alone to drive profitable growth. There should be a system of governance that would guide the strategic behavior in this direction.

The agency theory considers the financial market as a control mechanism that would induce managers to make strategic choices in the direction of the traditional value maximization (Jensen, 1993). Indeed, regulators of financial markets undertake to protect shareholders and ensure transparency of information. This is done, in part, through the obligation to publish annual reports and to inform shareholders about the strategies followed and their consequences in terms of value creation. Of course, this governance mechanism doesn't play the same role of control in the case of SMEs, because ownership remains highly concentrated in the hands of the leader, his associates and / or his family and the market is very illiquid, because of the weakness of the transactions. It remains no less true that it requires a minimum number of rules to protect minority shareholders and a high degree of transparency that would undermine the image of SMEs vis-à-vis its partners, in case of mismanagement. Managers must be vigilant in their mode of development and the expenses they incur. They must also comply with the promise of growth displayed. In short, in the context of the "glass house", the managers are not entirely free in their choices. Any strategic decision would be a signal about future prospects and would have a direct impact on shareholder value.

As such, signal theory is very instructive. Its purpose is to explain variations in stock prices through signals from the strategic decisions of managers. They must not only make fair decisions, but also convince the market by positive signals (Vernimmen, 2009). The examples most frequently cited concern the financial strategies: funding policy (Ross, 1977) and distribution (Charest, 1978). Investments in profitable projects are also a signal about future prospects of the company that would involve an appreciation in stock prices (Leland \& Pyle, 1977). In the absence of profitable growth, shareholders prefer to sell their shares, reap the liquidity and diversify their investment portfolio in more projects that create value.

Among the strategic levers of value, we can cite the external / internal growth strategies (Hoareau \& Teller, 2001; Hirigoyen \& Caby, 2001). The contribution of external growth strategies on creating shareholder value is rather negative. Such a strategy could potentially create value if it controlled and strengthened the bargaining power vis-à-vis a partner (customer, supplier, competitor), conquered new market share and mobilized synergies and economies of scale. But overall, it is clear from existing studies that this type of growth, often favored by a simple exchange of securities on the stock market is not creating value for shareholders of the acquiring firm. It especially allows an appreciation of the securities of the target company (Couret \& Hirigoyen, 1992; Caby, 1994) and a transfer of wealth in their favor, because of the offered premiums (Roll, 1986; Sudarsanam et al., 1993). Regarding the internal growth, many researchers have demonstrated a positive relationship between the market value of the company and its investment in capital assets (Mc Connel \& Muscarella, 1985), in research and development (Copeland et al., 1994; Chan et al., 1992) and generally, in any type of investments with a long-term strategic significance (Woodbridge, 1988).

In summary, this literature review shows that SMEs suffer from financing problems that hinder their growth. The stock exchange could be a solution which facilitates access to financial resources, enhances the reputation, social 
capital and thus increases the bargaining power vis-à-vis national or international partners. At the same time, it subjects them to constraints of transparency and to pressures of stock prices that should guide their strategic growth choices toward creating value. In what follows we will attempt to verify these assumptions. Our goal, to recall, is to study the impact of stock exchange listing on the SME growth (measured in terms of turnover) and the strategic choices related to it (preferred modes of growth).

\section{Methodology}

We conducted a longitudinal study, over a period of seven years (Note 3) (three years before listing, the listing year, and three years after) between 1991 and 2001 (Note 4). The study involved 65 listed SMEs and a control sample of similar unlisted SMEs (Note 5) whose turnover is less than 50 million at the date of IPO (Note 6). Such a criterion is inadequate given the variety of industries to which firms belong. Careful attention was paid to each company, given its turnover, its workforce and its branch of industry (see Table 1). The information was collected from the database Diane, CD-pro, and Dafsaliens supplemented by annual reports available in the documentation center of the AMF.

\section{Insert Table 1 Here}

The study (Note 7) was conducted in two stages corresponding to the two procedures proposed by Alexander and Charreaux (2004). The first step is used to test the "static evolution" of the growth indicators. This is in order to monitor these indicators on average, before / after listing (longitudinal comparison) and listed / unlisted SMEs (cross-sectional comparison). Parametric tests have been conducted to see if the differences are statistically significant. To better reflect the evolution of indicators over time, we operated the same tests on the extreme years $(-3 /+3)-3 / 0$ (pre-listing period) and $0 /+3$ (post-listing period). That said, the dynamic effect of the stock exchange listing is perceived very imperfectly.

To overcome this deficiency, like Alexander and Charreaux (2004), we felt it necessary to use an econometric model that allows us to take into account the temporal dynamics and to check whether the listing is a significant explanatory variable of the growth, ceteris paribus. For this, the main growth indicators were regressed on 1) the time $\mathrm{T}$ (the values from 1 to 7 denoting the seven years). This is to monitor indicators of growth over the 7 years period, 2) a dummy variable reflecting the listing L (equals 1 if the company is listed, 0 otherwise). This variable allows us to verify if the listing is significantly explanatory of growth in a positive or negative sense and 3) a variable TL equal to the product of the variable "time" and the dummy variable "listing". This is the variable that seems most relevant to monitor the dynamics of growth over the years after listing. Finally, to improve the quality of the model, two control variables, common to all businesses, have been introduced: the size and the business cycle. The regression method that we considered most suitable is that of generalized least squares applied to panel data (455 observations). It is used to control the unobserved heterogeneity that is often a source of statistical bias, to correct the heteroscedasticity that appears in the variance-covariance matrix and to identify the observable determinants of differences in behaviors. The regression model is as follows:

$$
G r_{i t}=\alpha_{i}+\beta_{1 i} T_{i t}+\beta_{2 i} L_{i t}+\beta_{3 i} T L_{i t}+\beta_{4} \text { size }_{i t}+\beta_{5} \text { cycle }_{i t}+\varepsilon_{i t}
$$

$G r_{i t}$ : the growth of firm $\mathrm{i}$ in year $\mathrm{t}$

$T_{i t} \quad$ : the time for the firm $\mathrm{i}$ (value ranging from 1 to 7 )

$L_{i t} \quad$ : a dummy variable scoring taking the value 1 in year $t$ of listing of the company $i$, and 0 otherwise

$T L_{i t}$ : a variable expressing the interaction of the two previous variables

size $_{i t}$ : a control variable, measured by turnover, the firm $\mathrm{i}$ in year $\mathrm{t}$

cycle $_{i t}$ : the rate of GDP growth in year $t$ for firm $\mathrm{i}$

$\varepsilon_{i t} \quad:$ the error term

Regarding growth indicators, we selected like Delmar et al. (2003) and Julien et al. (2006), sales growth as an indicator of organic growth. Boissin et al. (2010) consider this indicator as essential but not sufficient, and propose integrating, among other things, the international dimension. Concerning the growth patterns, we focused attention on the traditional methods of internal and external growth and investment in R\&D. The first model corresponds to the definition of "entreprise-patrimoine" in the sense of De Montmorillon (1989): the company grows by acquiring new productive assets, approximated by the ratio (Tangible assets / total fixed assets). The second corresponds to partial or total equity investment in the capital of other firms, for control purposes (Paturel, 1992). We approximate this growth mode by the ratio of financial assets / total fixed assets (Alexander \& Charreaux, 2004). Much research demonstrates the advantage of innovation and investment in R\&D to stimulate growth (St-Pierre \& Mathieu, 2003a). We therefore use the rate of investment in $R \& D(R \& D /$ total assets) as an indicator of growth through technological 
innovation. In addition to these modes of development, we added in the statistical analysis, the overall rate of investment (net fixed assets / Total net balance).

The following table summarizes all the indicators and theoretical or empirical work that helped us to build them:

Insert Table 2 Here

\section{Static Evolutions for Growth Indicators}

Table 1 presents the test results of the first procedure for listed and unlisted SMEs. (Note 8) For each indicator, are mentioned averages of the 65 companies surveyed in the year -3 (the third year before listing), 0 (the year of listing), 3 (third year after listing) and the average of three years before and after listing. The following columns indicate the mean difference tests. These tests verify whether the difference is significant or not.

Insert Table 3 Here (Note 9)

Regarding growth indicators, we find a variation of sales still positive on average in years $-3,0,+3$ and averages before and after listing. This means that there is a growth in turnover over the 7 years of observations. It remains no less true that this evolution occurs at a decreasing rate. Indeed, we observe the average of growth rate at $54 \%$ before listing and only $15 \%$ after listing. The difference is statistically significant. We have the same observation when we compare the date of the IPO and the third year after listing. That said, this trend also relates to the control sample, although the differences are not statistically significant. This is probably a general tendency due to the euphoria of the internet bubble that saw an explosion from the year 2000, causing a generalized fall in corporate activity. Faced with this increase in sales with a decreasing rate, the percentage abroad increases significantly by comparing the extreme years $(-3 /+3)$ and the post-listing period. This is far from being confirmed in the control sample: the differences are not significant and have a negative change over the past four years. Listing seems to promote the internationalization of SMEs through financial resources, reputation and the network effects it can generate.

As regards investment policy, listing seems to exert a significant effect on most indicators. Indeed, the global investment rate has increased from -3 to +3 ; from 0 to +3 and averages before and after listing. This trend is quite opposite in unlisted SMEs. The bulk of investments concern the external growth. The ratio of financial assets / total assets has been significantly increasing from $28 \%$ to $51 \%$ between the two extreme years $(-3$ to +3$)$. The trend is reversed for unlisted SMEs. As for tangible assets, the investment decreased significantly in all tests, from $60 \%$ to $34 \%$. The trend remains the same for the control sample, although the difference is not significant and lesser magnitude (from $28 \%$ to $25 \%$ ). Finally, the rate of investment on R\&D showed a significant decrease in average compared to the situation pre-listing. Conversely, the control sample shows a positive evolution of the rate of investment in R\&D, by comparing the extreme years and the upstream period. Listed SMEs seem to be skeptical when faced with this type of investment which is costly and uncertain. They largely favored external growth at the expense of internal growth.

This step has mainly helped us to monitor the evolution of the growth indicators statically, without being able to apply the rule of "all things being equal". Indeed, the differences, even significant, cannot be systematically attributed to the phenomenon of listing. For this reason, the empirical study was extended by an analysis that explains the impact of listing for each company and introduces the "time" variable in a more dynamic perspective.

\section{Dynamic Evolution of Growth Modes in a Listing Context}

Tables 4, 5, 6 present an extract of results obtained for the evolution of growth patterns for listed SMEs (internal/external growth and investment in R\&D). To better understand its content, consider the example of Cegedim company for which all coefficients are statistically different from zero. The $\mathrm{T}$ coefficient is negative: that means a decline of internal growth and investment in $R \& D$ for seven years. The trend is reversed for external growth. The $\mathrm{C}$ coefficient, also negative, means a decrease of the indicator of growth and investment in R\&D with listing. The positive sign for the external growth reflects a substitution effect between these two growth modes in favor of the external growth. Finally, the signs of the coefficients are reversed for the TC variable. The Cegedim company seems to favor over time after listing, internal growth and investment in technological innovation to the detriment of external growth.

Insert Table 4 Here

Insert Table 5 Here

Insert Table 6 Here

Like Alexander and Charreaux (2004), we assume that the two control variables (size and business cycle), which condition the growth, are common to all businesses. In other words, the impact of these two variables is identical for all firms. Here in this case, the size effect is negative for internal growth and vice versa for acquisitions and 
investment in R\&D: the larger the company, the lower its need to invest in production capacity. The large size seems to favor external growth and technological innovation. Regarding the economic cycle, it appears that the high rate of GDP incites companies to invest more in internal growth.

For each company, we have estimation for the time and listing variables. It appears that the listing has had a positive effect on investment in technological innovation in 13 cases out of65. This positive effect is only significant for only 3 cases. The negative effects are more meaningful in 52 cases (though not significant). However, the most interesting coefficient is one that reflects the evolution of strategy over time after listing, in a more dynamic perspective: the TC coefficients. They are positive for 48 SMEs but significant for only 2 companies. They are, however, negative and significant in 6 cases. The listing appears to have a negative effect on investment in R\&D. This is confirmed in our statistical results. Note also a possible change in trend on a longer horizon, because we spend from 13 positive coefficients for the $\mathrm{C}$ variable to 48 for the TC variable. Since its introduction, SME leaders don't encourage the realization of such an investment which is costly and whose recovery time is very slow. This would impact negatively on the immediate results of the company and its share price on the stock market. However, beyond three years of listing, management doesn't preclude the realization of such an investment which is often effective in improving performance. Our results and interpretations that are derived are different from those of Welbourne et al. (1998), cited above.

Regarding the strategy of internal growth, the effect of listing is positive for 28 out of 65 SMEs, but it is positive and significant for only 8 SMEs. The negative effect is more significant in 13 cases and 37 non-significant. The coefficients of the TC variable provide information of a dynamic nature. They are positive in 31 SMEs but are positive and significant in 18 cases. However, they are negative for 34 SMEs and negative and significant for 27 SMEs. Internal growth doesn't seem to be favored in a listing context (both in static and dynamic optical). These results are consistent with results obtained in the framework of the statistical study. This would probably tend towards the destroying of value in view of the work of Mc Connel and Muscarella (1985).

Finally, with regard to external growth, the effect of listing is positive in 40 cases. This effect is significant only in 16 SMEs. However, the negative coefficients are present in 13 non-significant cases and 12 significant cases. This confirms the results of the statistical study: the listing has had a positive effect on the external growth strategy if we compare statically the change in this ratio compared to the situation before listing (risk of error 1\%) and in relation to unlisted SMEs. If we consider the dynamic evolution, the TC coefficient is positive in 28 SMEs and significant in 12 cases against 24 negative and significant coefficients. Apparently, most SMEs in our sample, attracted by the possibility to acquire securities by simple exchange of shares, have recourse to external growth after their IPO. Subsequently, this strategy declines over time. Thus, we would be tempted to temper our idea: the listing has had a positive effect on the external growth strategy in a static perspective. The trend reversed with time. It should be remembered that this type of growth strategy is not necessarily a positive signal. Many authors have demonstrated its destructive value effects (Roll, 1986; Hirigoyen \& Couret, 1992; Sudarsanam et al., 1993; Caby, 1994). It is especially true that shareholders, having the opportunity to diversify their portfolio, much prefer financial return to growth.

Finally, it appears that SMEs that have been listed in stock exchange market have renounced the basic mode of growth to make more acquisitions. They fear the costly investment of R\&D. But the trend seems to be reversed with time. They grow in the international markets and overall they increase their turnover. Growth patterns favored in this listing context are not necessarily creating value, in view of the studies cited above. This could provide some explanations to the decline in performance often found in empirical research.

\section{Conclusion}

SME growth is an important economic issue that mobilizes the interest of political and academic research. One major concern is to understand the obstacles which hinder the growth of SMEs and how to work around them. A recent study by the Bank of France (2010) showed that the presence on the stock market could be a solution that would foster growth momentum, thanks to financial resources and reputation that it can generate. At the same time, numerous studies have demonstrated a rather negative effect on performance (and Mansali Labegorre, 2010; Serve, 2007). Faced with this paradox, we wished to study, on the one hand, the impact of stock exchange listing on the SME growth and to analyze, on the other hand, the growth patterns that SMEs favor in the context of listing. Finally, we were able provide some answers regarding the decline in performance often recognised after listing and therefore make some recommendations on the growth choices that carry value for listed SMEs.

Our research reveals an overall rather positive effect on SME growth: the turnover continues to grow, despite a decreasing rate and the foreign turnover increases proportionally more on average. SMEs seem to focus on international growth. The overall rate of investment is growing on average. The bulk of investment is directed 
towards external growth, favored by the presence in the stock exchange market at the expense of internal growth and investment in technological innovation.

In the light of value theories, the financial market seems to guide the growth choices of SMEs in the direction of destroying value. That said, our results should be taken with nuance because the use of comparative statistics and an econometric model with panel data doesn't allow the generalization of results. The presence on the stock market doesn't systematically imply growth for all indicators used and for all SMEs in our sample. SMEs are extremely heterogeneous and don't develop all in the same way nor in the same degree when they are listed on the stock market. This is the general trend which is emerging. It allows us to provide some explanation for declines in performance often found in empirical studies. Further studies, making the connection between these growth choices and performance, need to be done to follow up this work. Similarly, qualitative studies could help us to bring us closer to the reality of SMEs and to understand their growth choices in this new environment.

\section{References}

Alexandre, H., \& Charreaux, G. (2004). L'efficacité des privatisations françaises: une vision dynamique à travers la théorie de gouvernance. Revue économique, 55(4), 791-821.

Banque de France. (2010). Entreprises cotées sur les marchés à faible capitalisation créés en 2005-2008. Observatoire des entreprises-PME cotées.doc, 1-10.

Becchetti, L., \& Trovato, G. (2002). The Determinants of Growth for Small and Medium Sized Firms. The Role of the Availability of External Finance. Small Business Economics, 19(4), 291-306. http://dx.doi.org/10.1023/A:1019678429111

Blowers, S. C., Ericksen, G. K., \& Milan, T. L. (1995). The Ernst \& Young guide to taking your company public. New York: John Wiley \& Sons.

Boissin, J. P., Chalus-Sauvannet, M. C., Deschamps, B., \& Geindre, S. (2010). Profils de dirigeants et croissance des jeunes entreprises. Cahier de recherche, n 2009-12 E4, Octobre.

Bruton, G. D., \& Prasad, D. (1997). Strategy and IPO Market selection: Implications for the Entrepreneurial Firm. Journal of Small Business Management, 1(10).

Caby, J. (1994). Motivations et efficacités des offres publiques d'achat et d'échange en France de 1970 à 1990 (Thèse de Doctorat de Sciences de Gestion). IAE de Nancy.

Caby, J., \& Hirigoyen, G. (2001). Création de valeur de l'entreprise. Economica, 2 ème édition.

Cai, J., \& Wei, J. (1997). The Investment and Operating Performance of Japanese Initial Offerings. Pacific-Basin Finance Journal, 5, 389-417. http://dx.doi.org/10.1016/S0927-538X(97)00021-8

Chan, S., Kensiguer, J. W., \& Martin, J. (1992). The Market Rewards Promising R and D and punishes the rest. Journal of Applied Corporate Finance, 5(2), 59-66. http://dx.doi.org/10.1111/j.1745-6622.1992.tb00490.x

Charest, G. (1978). Dividend Information, Stock Returns and Market Efficiency. Journal of Financial Economics, Juin-Septembre, 297-330. http://dx.doi.org/10.1016/0304-405X(78)90033-8

Coakley, J., Hadass, L., \& Wood, A. (2004). Post-IPO operating Performance, Venture Capitalists and Market Timing. Working Paper, University of Essex, Department of Accounting, Finance and Management, November.

Copeland, T., Koller, T., \& Murrin, J. (1994). Valuation: Measuring and Mmanaging the Value of Companies (2nd ed.). New York: Mc Kinsey and company, john Wiley and sons.

Couret, A., Hirigoyen, G., \& Caby, J. (1992). Les OPA, Que sais-je?. Paris: PUF.

Covin, J., \& Slevin, D. (1991). A conceptual Model of Entrepreneurship as Firm Behaviour. Entrepreneurship Theory and Practice, Fall, 7-25.

Daigne, J-F., \& Joly, X. (1986). Le second marché: un atout pour l'entreprise. Paris: Les éditions d'organisation.

De Montmorillon, B. (1989). Croissance de l'entreprise. Encyclopédie de gestion. sous la direction de Joffre, P. et Y. Simon, Paris, Economica, tome1.

Delmar, F., Davidson, P., \& Gartner, W. B. (2003). Arriving at the high growth firm. Journal of Business Venturing, (18), 189-216. http://dx.doi.org/10.1016/S0883-9026(02)00080-0

Fadil, N. (2007). Stratégie, gouvernance et performance des moyennes entreprises: quel est l'impact de la cotation en Bourse?. Management et Avenir, 1(11), 147-166. http://dx.doi.org/10.3917/mav.011.0147 
Hambrick, D. C., \& Crozier, L. N. (1985). Stumblers and Stars in the Management of Rapid Growth. Journal of Business Venturing, 1(1), 31-45. http://dx.doi.org/10.1016/0883-9026(85)90005-9

Hoarau, C., \& Teller, R. (2001). Création de valeur et management de l'entreprise. Paris: Vuibert.

Jain, B. A., \& Kini, O. (1994). The Post-issue Operating Performance of IPO Firms. Journal of Finance, 49(5), 1699-1726. http://dx.doi.org/10.2307/2329268

Jensen, M. C. (1993). Corporate Control and the Politics of Finance. In E. Altman (Ed.), Bankruptcy \& Distressed Restructurings. Stern, New York University Salomon Center, Irwin.

Julien, P. A., Saint Jean, E., \& Audet, J. (2006). Les facteurs influençant la croissance des PME à forte croissance, $23^{\text {ème }}$ colloque annuel du conseil canadien des PME et de l'entrepreneuriat, Trois-Rivières.

Kim, K., Kitsabunnarat, P., \& Nofsinge, L. J. (2002). Ownership Control and Operating Performance in an Emerging Market: Evidence from Thai IPO Firms. Journal of Corporate Finance, 156, 1-27.

Krasniqi, B. A. (2007). Barriers to entrepreneurship and SME growth in transition: The case of Kosova. Journal of Developmental Entrepreneurship, 12(1), 71-94. http://dx.doi.org/10.1142/S1084946707000563

Leland, H., \& Pyle, D. (1977). Informational asymmetries, financial structure, and financial intermediation. Journal of Finance, 32(2), 371-387. http://dx.doi.org/10.2307/2326770

Mansali, H., \& Labégorre, F. (2010). Les performances économiques et boursières à long terme des sociétés introduites en bourse: le cas du marché français (1990-2003). Finance Contrôle Stratégie, 13(2), 67-106.

Mc Connel, J., \& Muscarella, C. J. (1985). Corporate Capital Expenditure Decisions and the Market Value of the Firm. Journal of Financial Economics, 14(3), 399-422. http://dx.doi.org/10.1016/0304-405X(85)90006-6

Mikkelson, W. H., Partch, M. M., \& Shah, K. (1997). Ownership and Operating Performance of Companies that Go Public. Journal of Financial Economies, 44, 281-307. http://dx.doi.org/10.1016/S0304-405X(97)00006-8

Ministère de l'Economie des Finances et de l'Emploi. (2008). Les chiffres-clefs des PME (p. 337). Ed. Etudes \& Statistiques.

Oliveira, B., \& Fortunato, A. (2006). Firm Growth and Liquidity Constraints: A Dynamic Analysis. Small Business Economics, 27(2-3), 139-156. http://dx.doi.org/10.1007/s11187-006-0006-y

Pagano, M., Panetta, F., \& Zingales, L. (1998). Why do Companies Go Public: an Empirical Analysis. Journal of Finance, 53(1), 27-64. http://dx.doi.org/10.1111/0022-1082.25448

Pare, J. L., Redis, J., \& Sahut, J. M. (2009). The Development of Entrepreneurial Finance Research. International Journal of Business, 14(4), 283-290.

Paturel, R. (1992). Stratégie de croissance externe. Encyclopédie de management, tome 2, $2^{\text {ème }}$ édition. Paris. Vuibert. 407-417.

Pissarides, F. (1999). Is lack of funds the main obstacle to growth? ebrd's experience with small- and medium-sized businesses in central and eastern Europe. Journal of Business Venturing, 14(5-6), 519-539. http://dx.doi.org/10.1016/S0883-9026(98)00027-5

Ravasi, D., \& Marchisio, G. (2003). Going Public and the Enrichment of a Supportive Network. Small Business Economics, 21(4), 381-395. http://dx.doi.org/10.1023/A:1026119221991

Roll, R. (1986). The Hubris Hypothesis of Corporate Takeovers. Journal of Business, 59, 197-216. http://dx.doi.org/10.1086/296325

Ross, S. (1977). The Determination of Financial Structure: The Incentive - Signalling Approach. Bell Journal of Economics, 8, 23-40. http://dx.doi.org/10.2307/3003485

Sentis, P. (2001). Performances opérationnelles et boursières des sociétés introduites en Bourse: le cas français 1991-1995. Finance, 22(1), 87-118.

Serve, S. (2007). L'impact de l'admission à la cote sur les performances économiques des entreprises. Finance, 28(2), 79-120.

St-Pierre, J., \& Fadil, N. (2012). La recherche en finance entrepreneuriale: critique sur l'état actuel des connaissances et proposition d'un nouveau cadre de réflexion. Revue Internationale PME, à paraitre.

St-Pierre, J., \& Mathieu, C. (2003a). Innovation in Canadian SMEs: The Process, characteristics of firms and their environment. $48^{\text {th }}$ ICSB World Conference, Belfast, 15-18 juin. 
St-Pierre, J., \& Mathieu, C. (2003b). Le financement par capital risque: évolution des connaissances des dix dernières années et avenues de recherche. Rapport de recherche, Industrie Canada, 25 avril.

Sudarsanam, S., Holl, P., \& Salami, A. (1993). Shareholder Wealth Gains in Mergers: an Empirical Test of the Synergy and Agency Effects. Journée internationale de l'AFFI, La Baule.

Vernimmen, P. (2009). Finance d'entreprise. Ed. Dalloz Gestion.

Wang, C. (2005). Ownership and Operating Performance of Cjinese IPOs. Journal of Banking and Finance, 29, 1835-1856. http://dx.doi.org/10.1016/j.jbankfin.2004.07.003

Welbourne, T., Heidi, M., Necky, M., \& Dale Meyerz, G. (1998). Getting Past the Entrepreneurial Growth Ceiling: A longitudinal Study of IPO Firm Growth Through solution Driven Strategies. Center for Advanced Human Resource Studies, CAHRS Working Paper Series, Cornell University.

Woodbridge, J. R. (1988). Competitive Decline and Corporate Restructuring: Is a Myopic Stock Market to Blame? Journal of Applied Corporate Finance, 1(1), 26-36. http://dx.doi.org/10.1111/j.1745-6622.1988.tb00155.x

\section{Notes}

Note 1. Quoted by St-Pierre and Fadil (2012).

Note 2. Quoted by St-Pierre and Fadil (2012).

Note 3. We chose this time gap (7 years) for reasons of data availability and homogeneity of backgrounds and economic contexts. We could broaden the horizon for some companies, but the realization of an unbalanced panel in the model induce econometric and interpretation bias. This is especially true until 2001, the economic environment changes from a phase of euphoria of stock market to a crisis phase, which is not without impact on the financial and strategic choices of listed SMEs. Finally, some studies have mobilized quite similar time horizons (Megginson et al., 1994; Charreaux and Alexander, 2004) or shorter (Kim et al., 2002; Wang, 2005; Serve, 2007), without reducing the quality of their modeling and their results.

Note 4. To avoid interpretation bias, we opted for a period of stock market euphoria (Internet bubble) rather than a crisis. In the latter case, reduced growth could be attributed systematically to the crisis context. Conversely, if the company fails to grow in a period of euphoria, we might question the relevance of the IPO decision and its consequences, presumed positive, on the growth of SMEs.

Note 5. To create this sample, we relied on SMEs introduced in 1998 (which constitute almost $45 \%$ of our sample). For each company, we sought its "counterpart" unlisted, in the same size (in terms of numbers of employees and turnover) and in the same industry. Diane database allows us to conduct this type of selection by specifying the criteria mentioned.

Note 6. We relied on the definition of the European Commission (January 2005).

Note 7. The same method, with the same data, was been applied by Fadil (2007) for a general analysis of performance.

Note 8. This table and the associated results were extracted and adapted from Fadil (2007).

Note 9. For unlisted SMEs, we selected the horizon (1995-2001) because the majority of SMEs in our sample were introduced in 1998. They are analyzed on the same horizon. 
Table 1. Extract from listed SMEs and their key characteristics

\begin{tabular}{|c|c|c|c|c|c|}
\hline SMEs & $\begin{array}{l}\text { Date of IPO } \\
\text { (DIPO) }\end{array}$ & $\begin{array}{l}\text { Turnover } \\
\text { (K.€) in } \\
\text { DIPO } \\
\end{array}$ & $\begin{array}{l}\text { Number of } \\
\text { employees in } \\
\text { DIPO }\end{array}$ & Industry & $\begin{array}{l}\text { Compartment of Stock } \\
\text { Market in DIPO }\end{array}$ \\
\hline AIROX & 1997 & 8481 & 62 & Medical equipment Manufacturing & Marché libre OTC \\
\hline APEM & 1995 & 25423 & 313 & Switch Manufacturing & Second marché \\
\hline ASSYSTEME & 1995 & 21847 & 6 & Management Consulting & Second marché \\
\hline BELVEDERE & 1997 & 21639 & 7 & Food wholesaler & Nouveau Marché \\
\hline BERTHET & 1996 & 19420 & 125 & Glasses Manufacturing & Second marché \\
\hline CEGEDIM & 1995 & 40932 & 294 & Communications and marketing Services. & Second marché \\
\hline CREANET & 1994 & 4962 & 7 & Computers consulting & Marché libre OTC \\
\hline CREATIFS & 1997 & 18852 & 134 & Events services & Second marché \\
\hline CYBERNETIX & 1997 & 27858 & 177 & Automatisme Engineering & Second marché \\
\hline DEBUSCHERE & 1995 & 27013 & 189 & Design & Marché libre OTC \\
\hline DIGIGRAME & 1997 & 9654 & 39 & Manufacturing of compression card of sound. & Second marché \\
\hline DURAN & 1997 & 9853 & 84 & Technical servicesfor cinema and television & Nouveau Marché \\
\hline DYNAFOND & 1994 & 6575 & 44 & Foundryof metals & Marché libre OTC \\
\hline GENERAL INDUS & 1997 & 8975 & 10 & Chemical products wholsaler & Marché libre OTC \\
\hline $\begin{array}{l}\text { ICOM INFO } \\
\ldots\end{array}$ & 1996 & 10952 & 46 & Telecommunication and computer consulting & Second marché \\
\hline VERNEY-CARRON & 1998 & 7678 & 97 & Arm manufacturing & Lyon Stock Exchange \\
\hline $\begin{array}{l}\text { Sample } \\
\text { distribution/mean }\end{array}$ & $\begin{array}{l}\text { 1994: } 15 \% \\
1995: 8 \% \\
1996: 14 \% \\
1997: 20 \% \\
1998: 43 \%\end{array}$ & $\begin{array}{l}\text { Mean: } \\
22377 \mathrm{~K} €\end{array}$ & Mean: 119 & & $\begin{array}{l}\text { Second Marché: } 60 \% \\
\text { Nouveau marché: } 20 \% \\
\text { Marché libre: } 20 \%\end{array}$ \\
\hline
\end{tabular}

Table 2. Indicators of growth

\begin{tabular}{lll}
\hline Growth Indicators & Growth Mesure & Authors \\
\hline Sales growth & St - St-1 / St-1 & Julien et al. (2006) ; Delmar et al. (2003) \\
International growth & International sales (in \%) & Boissin et al. (2010) \\
overall rate of investment & net fixed assets / Total net balance & Alexandre et Charreaux (2004) \\
External Growth & Financial assets/total fixed assets & Alexandre et Charreaux (2004) ; Paturel (1992) \\
Internal Growth & Tangible assets/total fixed assets & De Montmorillon (1989) \\
Investment in R\&D & R\&D/total fixed assets & St-Pierre et Mathieu (2003b) \\
\hline
\end{tabular}


Table 3. Testing the effect of listing on the various indicators of growth for SMEs listed and unlisted (longitudinal and transverse comparisons)

\begin{tabular}{|c|c|c|c|c|c|c|c|c|c|}
\hline Indicators for listed SMEs & Mean at -3 & $\begin{array}{l}\text { Mean } \\
\text { before }\end{array}$ & Mean at 0 & $\begin{array}{l}\text { Mean } \\
\text { after }\end{array}$ & Mean at +3 & $\begin{array}{c}\text { test } \\
\text { before/after }\end{array}$ & test $-3 /+3$ & test-3/0 & test $0 /+3$ \\
\hline \multicolumn{10}{|l|}{ Ratios of activities growth } \\
\hline $\mathrm{St}-\mathrm{S} \mathrm{t}-1 / \mathrm{St}-1$ & 0.95 & 0.54 & 0.19 & 0.15 & 0.1 & $-2.10^{* *}$ & -1.58 & -1.40 & $-2.85^{* * *}$ \\
\hline$\%$ of international turnover & 19.11 & 21.56 & 22.25 & 23.54 & 27.27 & 0.82 & $2.72^{* * *}$ & 1.36 & $2.58^{* * *}$ \\
\hline \multicolumn{10}{|l|}{$\begin{array}{l}\text { Ratios of investissement } \\
\text { (en \%) }\end{array}$} \\
\hline Total Investment rate & 26.68 & 25.59 & 25.25 & 31.91 & 33.85 & $3.18^{* * *}$ & $2.82^{* * *}$ & -0.74 & $4.55^{* * *}$ \\
\hline External Growth & 28.06 & 28.11 & 39.77 & 47.61 & 50.96 & $5.61^{* * *}$ & $5.92^{* * *}$ & $3.66^{* * *}$ & $3.64^{* * *}$ \\
\hline Internal Growth & 60.19 & 58.4 & 47.18 & 38.21 & 34.57 & $-6.73^{* * *}$ & $-6.87^{* * *}$ & $-3.72^{* * *}$ & $-4.43^{* * *}$ \\
\hline R\&D Investment & 3.34 & 3.15 & 1.74 & 1.01 & 0.98 & $-1.78^{*}$ & -1.25 & -0.80 & -1.07 \\
\hline $\begin{array}{l}\text { Indicators for non listed } \\
\text { SMEs }\end{array}$ & $\begin{array}{c}\text { Mean at } \\
1995\end{array}$ & $\begin{array}{l}\text { Mean } \\
\text { before }\end{array}$ & $\begin{array}{c}\text { Mean at } \\
1998 \\
\end{array}$ & $\begin{array}{l}\text { Mean } \\
\text { after }\end{array}$ & $\begin{array}{c}\text { Mean at } \\
2001\end{array}$ & $\begin{array}{c}\text { test } \\
\text { before/after }\end{array}$ & test $95 / 01$ & $\begin{array}{c}\text { Test } \\
95 / 98\end{array}$ & $\begin{array}{c}\text { test } \\
98 / 01\end{array}$ \\
\hline \multicolumn{10}{|l|}{ Ratios of activities growth } \\
\hline St - S t-1 / St-1 & 0.48 & 0.2 & 1.86 & 0.12 & 0.16 & -1.17 & -0.92 & 0.80 & -1.00 \\
\hline$\%$ of abroad turnover & 14.65 & 14.99 & 17.53 & 18.54 & 16.29 & 0.73 & 0.49 & 1.47 & -0.45 \\
\hline \multicolumn{10}{|l|}{$\begin{array}{l}\text { Ratios of investissement } \\
\text { (en \%) }\end{array}$} \\
\hline Total Investment rate & 26.22 & 27.14 & 23.00 & 23.58 & 23.78 & $-0.03^{*}$ & -0.93 & -1.14 & 0.44 \\
\hline External Growth & 28.22 & 28.68 & 27.11 & 26.21 & 25.63 & -0.93 & -0.88 & -0.23 & -0.46 \\
\hline Internal Growth & 55.35 & 52.49 & 49.29 & 50.91 & 49.64 & -0.60 & -1.31 & -1.63 & 0.08 \\
\hline R\&D Investment & 0.30 & 0.75 & 0.62 & 0.25 & 0.55 & $-0.70^{*}$ & $0.40^{*}$ & $0.66^{*}$ & $-0.08^{*}$ \\
\hline
\end{tabular}

Note: ${ }^{*}$ Test rejecting the null hypothesis of the equality of means $10 \%\left({ }^{* *}\right.$ at $\left.5 \%\right)\left({ }^{* * *} 1 \%\right)$.

Table 4. Extract from the test results of the dynamic effect of listing on the investment in R\&D

\begin{tabular}{|c|c|c|c|c|c|c|}
\hline $\mathrm{C}$ & -0.02 & $-4.59^{* * *}$ & \multirow{3}{*}{\multicolumn{2}{|c|}{ Adjusted R2 }} & \multirow{3}{*}{0.31} & \\
\hline LSIZE? & 0.006 & $4.69^{* * *}$ & & & & \\
\hline CYCLE? & 0.024 & 0.969527 & & & & \\
\hline SMEs & T Coefficient & t-Statistic & L Coef. & t-Statistic & TL Coef. & t-Statistic \\
\hline AIROX & -0.01 & -0.34 & -0.00 & -0.07 & 0.00 & 0.10 \\
\hline APEM & 0.03 & $9.58^{* * *}$ & 0.05 & 1.61 & $(-0.04)^{* * *}$ & -6.22 \\
\hline ASSYSTEME & -0.01 & -1.21 & -0.003 & -0.45 & 0.001 & 0.74 \\
\hline BELVEDERE & -0.00 & -0.74 & -0.005 & -1.02 & 0.00 & 0.83 \\
\hline BERTHET BONDET & -0.00 & -1.38 & -0.004 & -0.76 & 0.001 & 1.07 \\
\hline CEGEDIM & -0.00 & $(-3.26)^{* * *}$ & -0.003 & -1.41 & $0.001^{* *}$ & 2.07 \\
\hline CREANET & 0.00 & 1.05 & 0.002 & 0.70 & -0.001 & -1.24 \\
\hline CREATIFS EXPO. & -0.01 & -0.91 & -0.00 & -0.08 & 0.000 & 0.26 \\
\hline CYBERNETIX & -0.00 & -1.14 & -0.002 & -0.25 & 0.001 & 0.50 \\
\hline DEBUSCHERE & -0.01 & -0.91 & -0.003 & -0.28 & 0.001 & 0.46 \\
\hline DIGIGRAME & -0.00 & -0.25 & -0.000 & -0.03 & -0.001 & -0.13 \\
\hline DURAN & $-5.81 \mathrm{E}-05$ & -0.08 & $-8.96 \mathrm{E}-05$ & -0.01 & -0.001 & -0.20 \\
\hline DYNAFOND & 0.00 & 0.42 & $-6.26 \mathrm{E}-05$ & -0.008 & -0.001 & -0.26 \\
\hline GENERAL INDUS. & -0.00 & -0.38 & 0.001 & 0.06 & 0.001 & 0.06 \\
\hline ICOM INFO. & -0.00 & -0.67 & -0.003 & -0.56 & 0.001 & 0.7 \\
\hline$\cdots$ & & & & & & \\
\hline VERNEY-CARRON & -0.008 & -1.59 & -0.018 & -0.41 & 0.007 & 0.84 \\
\hline
\end{tabular}


Table 5. Extract from the test results of the dynamic effect of listing on the internal growth

\begin{tabular}{|c|c|c|c|c|c|c|}
\hline $\mathrm{C}$ & $\mathbf{0 . 8 0}$ & $12.07^{* * *}$ & \multirow{3}{*}{\multicolumn{2}{|c|}{ Adjusted R2 }} & \multirow{3}{*}{0,82} & \\
\hline LSIZE & \multirow{2}{*}{$\begin{array}{c}-0.03 \\
1.56 \\
\end{array}$} & $(-3.00)^{* * * *}$ & & & & \\
\hline CYCLE & & $2.38^{* * *}$ & & & & \\
\hline SMEs & T Coefficient & t-Statistic & L Coef. & t-Statistic & TL Coef. & t-Statistic \\
\hline AIROX & 0.03 & $3.33^{* * *}$ & 0.02 & 0.47 & -0.03 & $(-2.62)^{* * *}$ \\
\hline APEM & -0.05 & $(-3.41)^{* * *}$ & 0.13 & 0.89 & 0.00 & 0.01 \\
\hline ASSYSTEME & -0.26 & $(-4.08)^{* * *}$ & -0.30 & -0.51 & 0.21 & $1.71^{*}$ \\
\hline BELVEDERE & -0.27 & $(-5.42)^{* * *}$ & -0.60 & -1.29 & 0.25 & $2.62^{* * *}$ \\
\hline BERTHET BONDET & -0.11 & $(-4.76)^{* * *}$ & -0.38 & $(-1.73)^{*}$ & 0.10 & $2.33^{* *}$ \\
\hline CEGEDIM & -0.17 & $-21.41^{* * *}$ & -0.39 & $(-7.72)^{* * *}$ & 0.14 & $12.45^{* * *}$ \\
\hline CREANET & -0.04 & -1.18 & -0.50 & $(-1.63)^{*}$ & 0.05 & 0.91 \\
\hline CREATIFS EXPO. & 0.02 & 1.55 & -0.03 & -0.25 & -0.10 & $(-3.12)^{* * *}$ \\
\hline CYBERNETIX & -0.04 & -1.02 & -0.32 & -0.79 & 0.07 & 0.84 \\
\hline DEBUSCHERE & 0.07 & $2.98^{* * *}$ & 0.31 & 1.38 & -0.09 & $(-1.95)^{* *}$ \\
\hline DIGIGRAME & 0.00 & 0.07 & 0.44 & 1.18 & -0.16 & $(-2.13)^{* *}$ \\
\hline DURAN & 0.02 & 1.33 & -0.01 & -0.07 & -0.11 & $(-2.87)^{* * *}$ \\
\hline DYNAFOND & 0.11 & $4.44^{* * *}$ & 0.29 & 1.22 & -0.12 & $(-2.50)^{* * *}$ \\
\hline GENERAL INDUS. & 0.10 & $1.99^{* * *}$ & 0.30 & 0.59 & -0.21 & $(-2.03)^{* *}$ \\
\hline ICOM INFO. & 0.06 & $1.86^{* * *}$ & 1.26 & $4.26^{* * *}$ & -0.35 & $(-5.65)^{* * *}$ \\
\hline$\ldots$ & & & & & & \\
\hline VERNEY-CARRON & 0.15 & $3.62^{* * *}$ & 0.76 & $1.95^{* *}$ & -0.26 & $(-3.19)^{* * *}$ \\
\hline
\end{tabular}

Table 6. Extract from the test results of the dynamic effect of listing on the external growth

\begin{tabular}{|c|c|c|c|c|c|c|}
\hline $\mathrm{C}$ & -0.03 & \multirow{2}{*}{$\begin{array}{l}(-4.36)^{* * *} \\
5.14^{* * *}\end{array}$} & \multirow{3}{*}{\multicolumn{2}{|c|}{ Adjusted R2 }} & \multirow{3}{*}{0.78} & \\
\hline LSIZE & \multirow{2}{*}{$\begin{array}{l}0.01 \\
-0.11\end{array}$} & & & & & \\
\hline CYCLE & & $(-1.90)^{* *}$ & & & & \\
\hline SMEs & T Coefficient & t-Statistic & L. Coef. & t-Statistic & TL Coef. & t-Statistic \\
\hline AIROX & 0.01 & $3.70^{* * *}$ & -0.13 & $(-5.15)^{* * *}$ & 0.03 & $5.59^{* * *}$ \\
\hline APEM & 0.13 & $5.72^{* * *}$ & 0.12 & 0.57 & -0.07 & -1.58 \\
\hline ASSYSTEME & 0.39 & $4.15^{* * *}$ & 0.63 & 0.71 & -0.34 & $(-1.89)^{*}$ \\
\hline BELVEDERE & 0.37 & $4.76^{* * *}$ & 0.95 & 1.30 & -0.38 & $(-2.54)^{* * *}$ \\
\hline BERTHET BONDET & 0.23 & $9.00^{* * *}$ & 0.69 & $2.85^{* * *}$ & -0.23 & $(-4.60)^{* * *}$ \\
\hline CEGEDIM & 0.26 & $48.43^{* * *}$ & 0.70 & $17.37^{* * *}$ & -0.24 & $-26.79^{* * *}$ \\
\hline CREANET & 0.11 & $2.15^{* *}$ & 0.79 & 1.57 & -0.20 & $(-1.96)^{* * *}$ \\
\hline CREATIFS EXPO. & 0.09 & $1.69^{*}$ & 0.28 & 0.53 & -0.04 & -0.39 \\
\hline CYBERNETIX & 0.12 & $2.23^{* *}$ & 0.61 & 1.21 & -0.15 & -1.52 \\
\hline DEBUSCHERE & 0.04 & $5.80^{* * *}$ & -0.00 & -0.03 & -0.03 & $(-2.24)^{* *}$ \\
\hline DIGIGRAME & 0.09 & $2.74^{* * *}$ & -0.20 & -0.61 & 0.07 & 1.05 \\
\hline DURAN & 0.08 & $2.55^{* * *}$ & 0.41 & 1.37 & -0.04 & -0.70 \\
\hline DYNAFOND & 0.00 & $2.87^{* * *}$ & -0.03 & $(-2.28)^{* *}$ & 0.005 & $1.89^{*}$ \\
\hline GENERAL INDUS. & 0.01 & 0.30 & -0.41 & -0.81 & 0.14 & 1.39 \\
\hline ICOM INFO. & 0.06 & $2.02^{* *}$ & -0.97 & $(-3.35)^{* * *}$ & 0.22 & $3.70^{* * *}$ \\
\hline$\ldots$ & & & & & & \\
\hline VERNEY-CARRON & -0.00 & -0.50 & -0.45 & $(-2.87)^{* * *}$ & 0.11 & $3.44^{* * *}$ \\
\hline
\end{tabular}

